\title{
Effect of pre-chlorination on the efficiency of iron and manganese removal from surface water by coagulation-flocculation using aluminium sulphate: case of the Okpara dam in the Republic of Benin
}

\author{
D. ZOGO ${ }^{1}$, L.M. BAWA ${ }^{2 *}$, H.H. SOCLO ${ }^{3}$, G. DJANÉYÉ-BOUNDJOU ${ }^{2}$ and \\ D. ATCHEKPE ${ }^{1}$ \\ ${ }^{1}$ Société Nationale des Eaux du Bénin (SONEB). \\ ${ }^{2}$ Laboratoire de Chimie de l'Eau, Faculté Des Sciences, Université de Lomé, BP 1515, Lomé, Togo. \\ ${ }^{3}$ Unité de Recherche en Ecotoxicologie et Etude de Qualité (UREEQ, Université d'Abomey-Calavi, Bénin. \\ *Corresponding author; E-mail: bawamoktar@yahoo.fr; Tél : (228) 32024 30, Fax: (228) 2218595.
}

\begin{abstract}
Okpara dam water contained significant amounts of iron and manganese that could be problematic for consumers. In this study, we perfected a deferrization and demanganization technique by coagulationflocculation preceded by chlorination. The maximum iron and manganese concentrations varied from 30 to 50 $\mathrm{mg} / \mathrm{L}$ and 1.5 to $4.5 \mathrm{mg} / \mathrm{L}$ respectively before treatment. Purification yields depended on the conditions of operation. Under the least favourable conditions (coagulation at free $\mathrm{pH}$ ), the removal yields varied from 10 to $73 \%$ for iron and from 2 to $24 \%$ for manganese. Under the best conditions (pre-chlorination and coagulation at $\mathrm{pH}$ 6.5), we obtained between 50 and $95 \%$ elimination for iron and 20 and $45 \%$ for manganese. The treatment was therefore little adapted for the removal of manganese.

(c) 2010 International Formulae Group. All rights reserved.
\end{abstract}

Keywords: Surface water, water clarification, chemical coagulant, coagulation-flocculation mechanism, deferrization, demanganization.

\section{INTRODUCTION}

Iron and, to a lesser degree, manganese are some of the most abundant elements in the earth's crust. They are found in waters emanating from soil leaching and industrial pollution. These elements in certain proportion pose no danger to human health or to the environment. But they cause esthetic and organoleptic inconveniences to users. Iron and manganese give a colouration to water that can stain linen and sanitary appliances. They also impart a metallic taste to water that can render its consumption disagreeable. In surface or ground waters, one finds iron and manganese in different chemical forms (dissolved, precipitated, free or complexed) and in variable concentrations (Myint and Barry, 1999; Omoregie et al., 2002; Muwanga and Barifaidjo, 2006). They may be present in concentrations of about 2 to $5 \mathrm{mg} / \mathrm{L}$ of iron and 0.5 to $2 \mathrm{mg} / \mathrm{L}$ of manganese (Ellis et al., 2000; Roccaro et al., 2007) or in concentrations that are markedly higher and capable of attaining $20 \mathrm{mg} / \mathrm{L}$ of iron and 5 $\mathrm{mg} / \mathrm{L}$ of manganese (Berbenni et al., 2000). 
The methods of elimination of iron and manganese from water consist of transforming the dissolved forms $\left(\mathrm{Fe}^{2+}\right.$ and $\left.\mathrm{Mn}^{2+}\right)$ by oxidation, into precipitates $\left(\mathrm{Fe}(\mathrm{OH})_{3}\right.$ and $\mathrm{MnO}_{2}$ ) followed by filtration. Oxidation can be carried out by means of powerful chemical oxidants like oxygen, chlorine, chlorine dioxide, ozone or potassium permanganate (El Araby et al., 2008; Katsoyiannisa et al., 2008) or biologically (Tekerlekopoulou and Vayenas., 2007; Katsoyiannisa et al., 2008; Qin et al., 2009; Tekerlekopoulou et al., 2008; Burgera et al., 2008). Predominantly physical processes like clarification and adsorption on precipitates or activated carbon are evoked (Llofd et al., 1983; Aziza and Smith, 1992; Okoniewsk et al., 2007). Simple membrane techniques often preceded by oxidation are also cited among the processes of water deferrization and demanganization (Ellis et al., 2000; Teng et al., 2001; Choo et al., 2005).

Iron and manganese, when not removed, can be progressively oxidized in the distribution network giving water colour, taste, smell, turbidity and favouring the development of micro-organisms with undesired consequences for users health.

The objective of this work was to find a technique of iron and manganese removal from a dam raw water that feeds a potable water treatment plant. We tested a clarification method with and without chemical oxidation. The coagulant used was aluminium sulphate, and chlorine, the oxidant in the form of calcium hypochlorite.

\section{MATERIALS AND METHODS}

\section{Study area}

The dam is built at Parakou on a tributary of the mono river, called Okpara, in the North-East of Benin about $450 \mathrm{~km}$ from Cotonou. The watershed of this dam is situated in the eastern part of the town and extends to the districts of Tchaourou, Pèrèrè, Nikki, N'dali, then to part of the south-east of Bembereke district. Parakou is situated at latitude $9^{\circ} 21$ north and longitude $2^{\circ} 36$ east. The dam supplies the potable water treatment plant of the town.

\section{Methods of analysis and testing}

Water samples were taken from the surface $(0.2 \mathrm{~m})$ or at depths of from 2.0 to 4.5 $\mathrm{m}$ in $25 \mathrm{~L}$ plastic containers on the day of testing. The electrical conductivity and $\mathrm{pH}$ of the samples were measured using an LF 340A/SET conductimeter, and a WTW pH 340/ion SET pH-meter respectively. Iron and manganese were measured using the orthophenanthroline at $510 \mathrm{~nm}$ and the acid medium potassium periodate at $525 \mathrm{~nm}$ methods respectively. A DR $4000 \mathrm{U}$ spectrophotometer model 48100 was used to measure absorbency. Alkalinity was obtained by volumetric titration. The solutions were prepared from bidistilled water. Chlorine stock solution was prepared with calcium hypochlorite $\left(\mathrm{Ca}(\mathrm{OCl})_{2}, 65-70 \%\right)$ purchased from HTH, Granular. Chlorine, in a concentrated medium, was measured by iodometry and by the DPD $(\mathrm{N}, \mathrm{N}-$ Diethylphenylene-1,4-diamine) method in a dilute medium. Orthophenantroline (> 99\%), potassium periodate (> 99\%) and DPD $(97 \%)$ were purchased respectively from Acros Organics, Pancreac Quimica SA and AldrichChemie. The methods of analysis were based on the French association of standards (AFNOR, 1986).

Coagulation-flocculation tests were carried out according to the jar test protocol using an Orchidis 6-post miniflocculator equipped with a time switch and a tachometer. The volumes of water in the beakers were fixed at1litre each.

The different coagulation-flocculation phases consisted of a rapid agitation phase at a 
speed of $150 \mathrm{rpm}$ for $3 \mathrm{~min}$ and a slow agitation phase at a speed of $25 \mathrm{rpm}$ for 15 min. The samples were then allowed to settle for at least $30 \mathrm{~min}$ and the settled water filtered using a $0.22 \mu \mathrm{m}$ pore size Whatman filter paper.

The addition of the coagulant made of aluminium sulphate $\left(\mathrm{Al}_{2}\left(\mathrm{SO}_{4}\right)_{3} \cdot 18 \mathrm{H}_{2} \mathrm{O}\right)$ and lime for $\mathrm{pH}$ correction took place during the rapid agitation phase. Aluminium sulphate (17-18\% as $\left.\mathrm{Al}_{2} \mathrm{O}_{3}\right)$ and lime (> 92\%) were purchased respectively from Société Tunisienne des Produits Alumineux, STPA and Balthazard et Cotte.

The raw water tested did not undergo any pre-treatment. The tests took place within 24 hours of sampling.

\section{RESULTS}

Iron and manganese contents in the dam water

The raw water was characterized by low total salinity (40 to $80 \mathrm{mg} / \mathrm{L}$ ) and alkalinity (30 to $50 \mathrm{mg} / \mathrm{L} \mathrm{CaCO}_{3}$ ) and a $\mathrm{pH}$ between 6.7 to 5.6. The seasons of the year have a remarkable effect on the characteristics of the water.

We monitored variations in iron and manganese contents as function of time and space. The results showed low variation in iron and manganese contents at the water surface in all seasons on one hand. On the other hand, the contents of these metals in depth were practically zero between the months of June and October. One noted an increase in these contents from the month of November to June, reaching a peak between May and June. The maximum values for iron varied from 30 to $50 \mathrm{mg} / \mathrm{L}$ and manganese 1.5 to $4.5 \mathrm{mg} / \mathrm{L}$.

Figures 1 and 2 show two examples of the evolution of dissolved iron, manganese and oxygen concentrations with water column depth. One observed generally that the concentrations of these metals varied little for depths below $2 \mathrm{~m}$. From the $3 \mathrm{~m}$ depth, the concentrations increased rapidly, reaching the maximum value at the bottom of the dam. The study showed moreover that the variation in oxygen concentration was reversed compared to those of iron and manganese. Iron and manganese concentrations were more significant in the zones of low oxygen content. For example, Figures 1 and 2 show that in the more aerated superficial parts of the dam (about 4 to $5 \mathrm{mg} / \mathrm{L}$ of dissolved oxygen), the concentrations were $0.5 \mathrm{mg} / \mathrm{L}$ for iron and $0.2 \mathrm{mg} / \mathrm{L}$ for manganese. At the $4.5 \mathrm{~m}$ depth, we measured about $5.0 \mathrm{mg} / \mathrm{L}$ for iron and 2.6 $\mathrm{mg} / \mathrm{L}$ for manganese and the oxygen contents were low or practically null.

\section{Coagulation-flocculation at free pH}

Tests were carried out for doses of aluminium sulphate between 10 and $60 \mathrm{mg} / \mathrm{L}$. The residual concentrations were measured on decanted and filtered water. The results on Figure 3 show that clarification process allowed partial removal of the iron and manganese. The residual concentration of iron was about 1 to $1.5 \mathrm{mg} / \mathrm{L}$ for an initial value of $8 \mathrm{mg} / \mathrm{L}$ and a coagulant dose of between 50 and $60 \mathrm{mg} / \mathrm{L}$. For the same doses of coagulant, the manganese concentration was brought down from 1.08 to $0.9 \mathrm{mg} / \mathrm{L}$.

To appreciate the influence of prechlorination on the yield of iron and manganese removal, a dose of $4 \mathrm{mg} / \mathrm{L}$ of chlorine was applied to raw water at free $\mathrm{pH}$. A reaction time of about one hour was necessary. The residual chlorine was about 0.5 $\mathrm{mg} / \mathrm{L}$. The results obtained (Figure 4) after pre-chlorination showed that chlorination allowed improving the efficiency of the treatment. For a coagulant dose of $50 \mathrm{mg} / \mathrm{L}$, the residual concentration of manganese decreased from 1.1 to $0.7 \mathrm{mg} / \mathrm{L}$ and the final concentration of iron was below $0.3 \mathrm{mg} / \mathrm{L}$. In 
all cases, the iron concentration decreased steadily while that of manganese stabilized with 30 to $40 \mathrm{mg} / \mathrm{L}$ of coagulant.

\section{Coagulation-flocculation at pH 6.5}

The experiments were carried out at a $\mathrm{pH}$ of 6.5 with or without pre-chlorination. The results (Figures 5 and 6) show that at $\mathrm{pH}$ 6.5 the removal yields for iron and manganese were significantly improved.

Tables 1 and 2 compile the results of the iron and manganese removal tests at free $\mathrm{pH}$ or $\mathrm{pH} 6.5$ with or without pre-chlorination and for different initial concentrations of iron and manganese in raw water sampled at different depths. The results showed that for an initial iron concentration between 8 and 35 $\mathrm{mg} / \mathrm{L}$ and for a coagulant dose of $40 \mathrm{mg} / \mathrm{L}$ :

- Iron removal yield lay between 57 and 74\% during treatment at free $\mathrm{pH}$. This yield increased to $90 \%$ for tests on pre-chlorinated water,

- At pH 6.5, without chlorination the yield was about $75 \%$ and could reach $95 \%$ after pre-chlorination.

Moreover, the results showed the same trends in the case of the manganese removal test. Nevertheless the yields hardly reached $50 \%$.

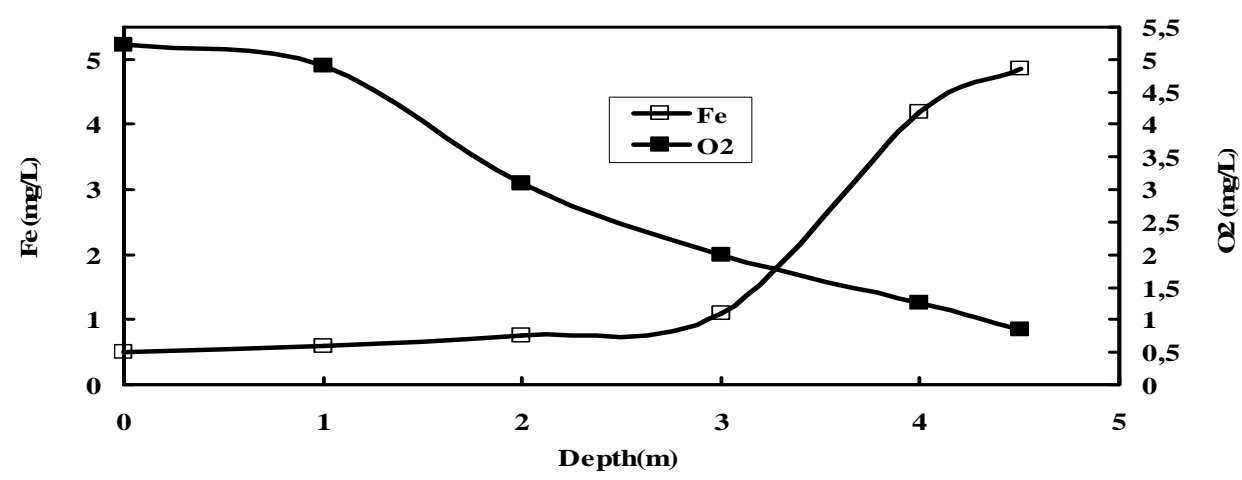

Figure 1: Evolution of dissolved iron and oxygen concentrations as a function of water column depth (July, 2006).

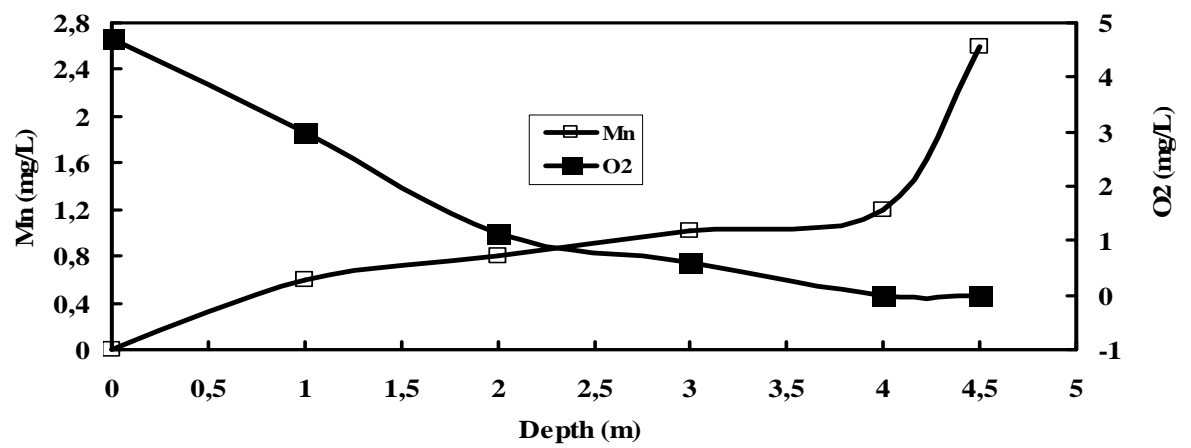

Figure 2: Evolution of dissolved manganese and oxygen concentrations as a function of water column depth (April, 2006). 


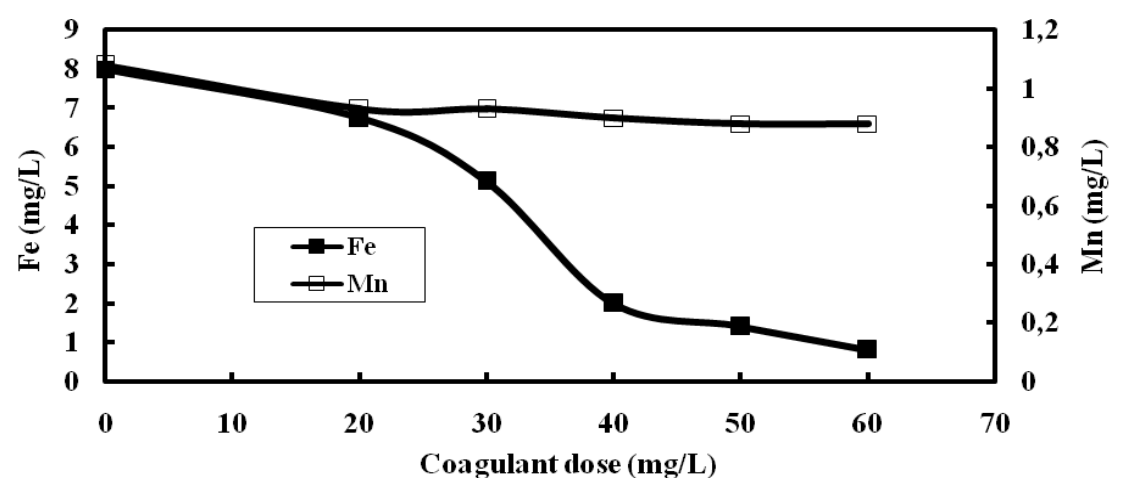

Figure 3: Removal of iron and manganese by coagulation at free $\mathrm{pH}$.

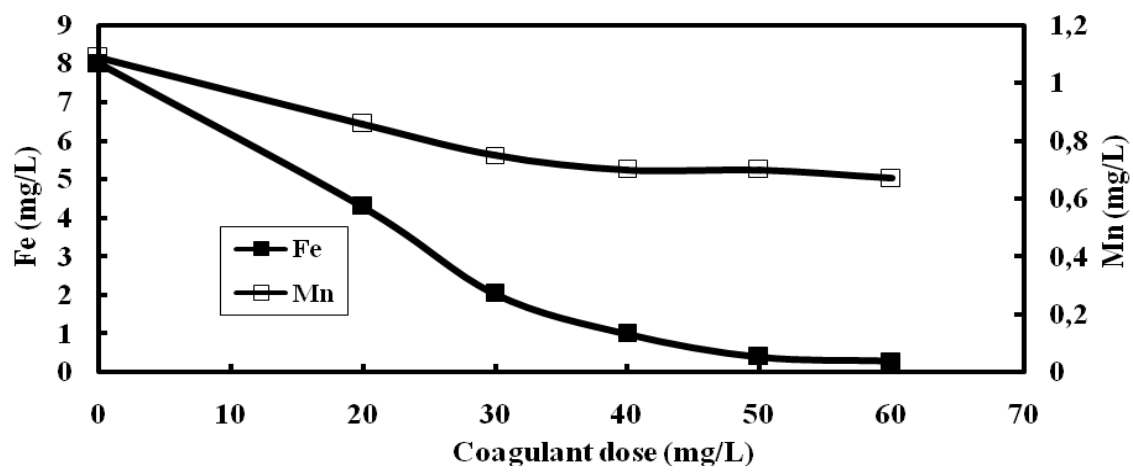

Figure 4: Removal of iron and manganese from pre-chlorinated water by coagulation at free $\mathrm{pH}$.

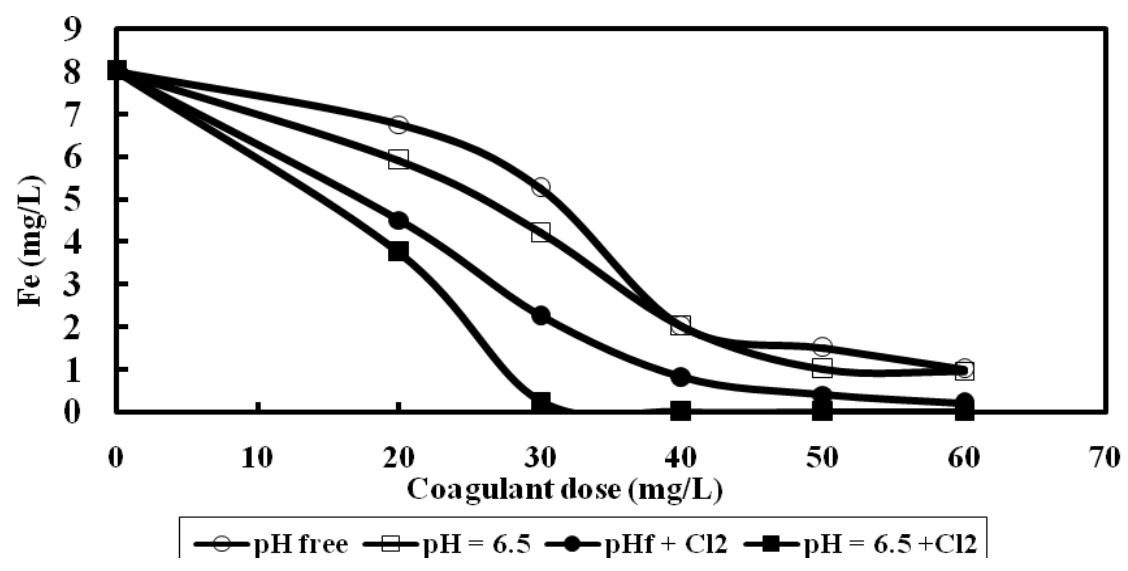

Figure 5: Removal of iron by coagulation with aluminium sulphate at free $\mathrm{pH}$ and $\mathrm{pH} 6.5$ with or without pre-chlorination. 


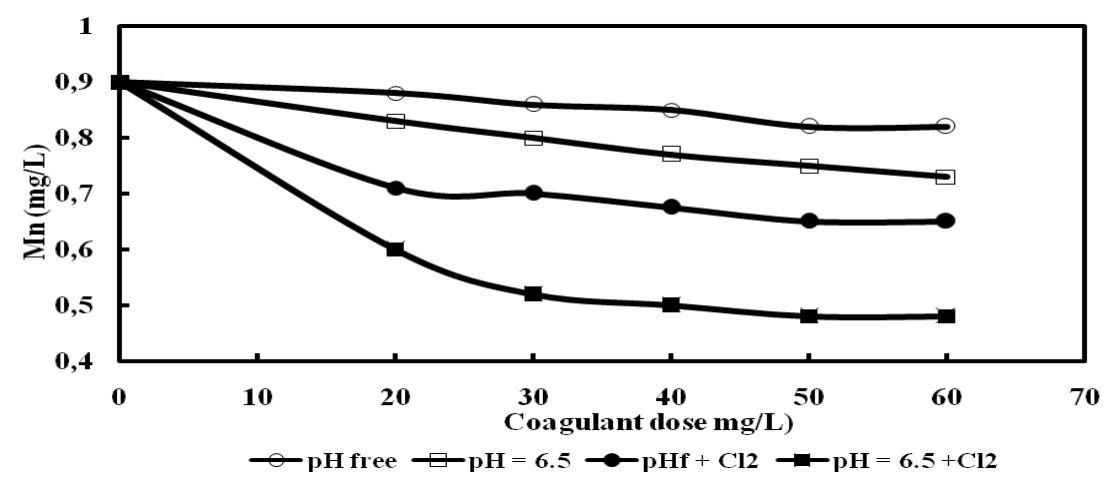

Figure 6: Removal of manganese by coagulation using aluminium sulphate at free $\mathrm{pH}$ and $\mathrm{pH} 6.5$ with or without pre-chlorination.

Table 1: Removal yields (\%) for iron and manganese using $40 \mathrm{mg} / \mathrm{L}$ of coagulant at free $\mathrm{pH}$ with or without pre-chlorination.

\begin{tabular}{cccccc}
\hline Fe (mg/L) & Mn (mg/L) & \multicolumn{2}{c}{$\begin{array}{c}\text { Coagulation } \\
\text { free } \mathbf{~ p H}\end{array}$} & \multicolumn{2}{c}{$\begin{array}{c}\text { Pre-chlorination } \\
\text { and coagulation } \\
\text { free } \mathbf{~ p H}\end{array}$} \\
\cline { 3 - 6 } & & $\mathbf{\% F e}$ & $\mathbf{\% M n}$ & \% Fe & \% Mn \\
\hline 8.0 & 1.1 & 73.8 & 23.7 & 88.8 & 35.2 \\
17.0 & 0.9 & 69.4 & 5.6 & 89.4 & 25.6 \\
24.0 & 2.0 & 70.4 & 5.0 & 89.6 & 20.0 \\
35.0 & 4.1 & 65.0 & 12.2 & 89.7 & 31.7 \\
\hline
\end{tabular}

Table 2: Removal yields (\%) for iron and manganese using $40 \mathrm{mg} / \mathrm{L}$ of coagulant at $\mathrm{pH} 6.5$, with or without pre-chlorination.

\begin{tabular}{cccccc}
\hline Fe (mg/L) & Mn (mg/L) & \multicolumn{2}{c}{ Coagulation pH 6.5 } & \multicolumn{2}{c}{$\begin{array}{c}\text { Pre-chlorination } \\
\text { and coagulation pH 6.5 }\end{array}$} \\
\cline { 3 - 5 } & & \% Fe & \% Mn & \% Fe & \% Mn \\
\hline 8.0 & 1.1 & 75.2 & 21.1 & 94.8 & 44.7 \\
17.0 & 0.9 & 75.0 & 14.4 & 94.7 & 44.4 \\
24.0 & 2.0 & 75.0 & 10.0 & 95.0 & 26.0 \\
35.0 & 4.1 & 75.0 & 17.1 & 94.8 & 41.5 \\
\hline
\end{tabular}

\section{DISCUSSION}

At free water $\mathrm{pH}$ or $\mathrm{pH} 6.5$ we determined iron and manganese removal yields by coagulation. The influence of $\mathrm{pH}$ was not systematically investigated because several studies show that the range of $\mathrm{pH}$ favourable for coagulation with aluminium sulphate lies between 5.5 and 6.5 or even between 5.0 and 7.00 (Van Benschoten et al., 1990; Gregor et al., 1997; Bawa et al., 2008 ; Zhong et al., 2010).

We showed that coagulation allowed the removal of a significant proportion of iron and manganese. The eliminated fractions are 
present in different forms (hydroxides, oxides) sometimes associated with solid particles like clays. We observed that the elimination of iron declined steadily as the concentration of coagulant increased while manganese removal tended to stabilize from 30 to $40 \mathrm{mg} / \mathrm{L}$ of coagulant. Higher doses of up to $60 \mathrm{mg} / \mathrm{L} \mathrm{did}$ not improve manganese elimination neither did they cause the restabilization of flocs. Knocke et al. (1992) obtained $63 \%$ of total iron elimination during the coagulation of raw river water using aluminum sulphate (coagulant dose from 40 to $50 \mathrm{mg} / \mathrm{L}, \mathrm{pH}$ between 6.3 and 6.5 , initial iron concentration from 0.6 to $2.4 \mathrm{mg} / \mathrm{L}$ ) and Montiel et al. (1990) obtained a manganese removal yield of from 25 to $30 \%$ (initial concentration of 0.5 to $1.0 \mathrm{mg} / \mathrm{L}$ ) during coagulation using ferric chloride in the presence of alginate at $\mathrm{pH}$ between 7.6 and 7.8.

Many mechanisms of particle elimination by coagulation (complexation between hydrolyzed soluble forms of metals and organic or colloidal matter, double layer reduction, adsorption on flocs of metallic hydroxides, charge neutralization, particle trapping and co-precipitation) are generally evoked in coagulation-flocculation studies. The conditions of treatment, particularly the $\mathrm{pH}$, may favour some approaches. Thus, JianJun et al. (2006) and Zhong et al. (2010) showed that between $\mathrm{pH} 4.5$ and 6.2 the contribution of the charge neutralization mechanism is more important. At $\mathrm{pH}$ greater than 5.5, the contribution of coagulation by neutralization decreases and the mechanism of coagulation by adsorption combined -with trapping and co-precipitation dominates. It was therefore probable that in this study the mechanism of particle neutralization was dominant during coagulation at free water $\mathrm{pH}$ (the $\mathrm{pH}$ decreased rapidly after coagulant addition toward 4.5 to 5.4 ). The mechanism by adsorption was dominant at $\mathrm{pH} 6.5$ (the $\mathrm{pH}$ having varied between 6.5 and 6.0). Adsorption can be direct on solid aluminium hydroxide or indirect after complex formation. It is recently shown that at $\mathrm{pH}$ between 4.5 and 9.0, aluminium in the form of sulphate in water is hydrolyzed forming 8 products of hydrolysis $\quad\left(\mathrm{Al}^{3+}, \quad \mathrm{Al}(\mathrm{OH})^{2+}, \quad \mathrm{Al}(\mathrm{OH})_{2}{ }^{+}\right.$, $\mathrm{Al}(\mathrm{OH})_{3}, \quad \mathrm{Al}(\mathrm{OH})_{4}{ }^{-}, \mathrm{Al}_{2}(\mathrm{OH})_{2}{ }^{4+}, \mathrm{Al}_{3}(\mathrm{OH})_{4}{ }^{5+}$ and $\left.\mathrm{AlO}_{4} \mathrm{Al}_{12}(\mathrm{OH})_{24}\left(\mathrm{H}_{2} \mathrm{O}\right)_{12}{ }^{7+}\right)$. Solid aluminum hydroxide $\mathrm{Al}(\mathrm{OH})_{3}$ is the main form of the total aluminum added to water and the cation containing 13 atoms of aluminum $\left(\mathrm{AlO}_{4} \mathrm{Al}_{12}(\mathrm{OH})_{24}\left(\mathrm{H}_{2} \mathrm{O}\right)_{12}{ }^{7+}\right)$ is the most important for the neutralization and destabilization of colloids which are generally negatively charged (Xiao et al., 2007). Franceshi et al. (2002) also showed that between $\mathrm{pH} 6$ and 8, the mechanism of clay elimination responsible for water turbidity is adsorption and neutralization.

With regard to the coagulationflocculation carried out at $\mathrm{pH} 6.5$, prechlorination allowed to increase removal yield from 50 to $95 \%$. During the tests, we noticed that yield increase became more significant as the test shifted to the deeper parts of the dam. Actually, the addition of chlorine during preoxidation contributes to oxidizing organic compounds like humic substances and inorganic compounds like the soluble forms of iron and manganese $\left(\mathrm{Fe}^{2+}, \mathrm{Mn}^{2+}\right)$. It is shown that oxidized forms of iron $\left(\mathrm{Fe}(\mathrm{OH})_{3}\right)$ and manganese $\left(\mathrm{MnO}_{2}\right)$ are good adsorbants (Mazet et al.,1990; Berbenni et al., 2000). It was therefore probable that the oxidized forms of iron and manganese, in playing the role of adsorbant, contributed generously to improving the efficiency of coagulation (coagulation by adsorption, trapping and by co-precipitation). Pre-oxidation was more productive for iron than manganese removal. One can accept that a good portion of the manganese is present in forms that are not easily oxidizable like organic complexes (Giannissis et al., 1985). Under our experimental conditions ( $\mathrm{pH}$ about 6.5, applied dose of $5 \mathrm{mgCl}_{2} / \mathrm{L}$ and a reaction time of 30 minutes), the chlorine applied was 
preferentially used up by organic matter (humic substances) and by the free forms of iron. The residual chlorine of $0.5 \mathrm{mg} / \mathrm{L}$ did not allow the efficient elimination of manganese.

\section{Conclusion}

The water studied in this paper contained significant amounts of iron and manganese. For a better appreciation of water quality by consumers, it was necessary to propose an efficient method of deferrization and demanganization. We tested the method of coagulation-flocculation preceded by chlorination. Under the best conditions (prechlorination and coagulation at $\mathrm{pH} 6.5$ ), the yields obtained were 50 to $95 \%$ for iron and 20 to $45 \%$ for manganese. Manganese was therefore less well eliminated. It would therefore be necessary to find another method that will be better able to eliminate both iron and manganese simultaneously.

\section{REFERENCES}

AFNOR. 1986. Eaux, Méthodes d'Essai (3 ${ }^{\text {ème }}$ edn). Afnor : Paris.

Aziza HA, Smith PG. 1992. The influence of $\mathrm{pH}$ and coarse media on manganese precipitation from water. Water Res., 26(6): 853-855.

Bawa LM, Djanéyé-Boundjou G, Soulémane AG, Kpékpassi L. 2008 Etude de la clarification d'une eau de surface par une substance naturelle (les extraits de Moringa Oleifera Lam): Incidence sur la demande en chlore. Phys. Chem. News, 42: 133-138.

Berbenni P, Pollice A, Canziani R, Stabile L, Nobili F. 2000 Removal of iron and manganese from hydrocarboncontaminated groundwaters. Bioresou. Technol., 74: 109-114.

Burgera MS, Mercera SS, Shupe GD, Gagnon GA. 2008. Manganese removal during bench-scale biofiltration. Water Res., 42(19): 4733-4742.
Choo KH, Lee H, Choi SJ. 2005 Iron and manganese removal and membrane fouling during UF in conjunction with prechlorination for drinking water treatment. J. Membr. Sci., 267: 18-26.

El Araby R, Hawasha S, El Diwania G. 2009 Treatment of iron and manganese in simulated groundwater via ozone technology. Desalination, 249(3): 13451349.

Ellis D, Bouchard C, Lantagne G. 2000 Removal of iron and manganese from groundwater by oxidation and microfiltration. Desalination, 130: 255264.

Franceschi M, Girou A, Carro-Diaz, AM, Maurette MT, Puech-Costes E. 2002. Optimisation of the coagulationflocculation process of raw water by optimal design method. Water Res., 36: 3561-3572.

Giannissis D, Le Cloirec P, Dorance G, Martin G. 1985 Efficacité de la chloration sur l'élimination du manganèse en présence de substances humiques. Aqua, 4: 199-203.

Gregor JE, Nokes CJ, Fenton E. 1997 Optimising natural organic matter removal from low turbidity waters by controlled $\mathrm{pH}$ adjustment of aluminium coagulation. Water Res., 31(12): 29492958.

Jian-Jun Q, Maung HO, Kiran AK, Frans K, Peter M. 2006 Impact of coagulation $\mathrm{pH}$ on enhanced removal of natural organic matter in treatment of reservoir water. Sep. Purif. Technol., 49(3): 295-298.

Katsoyiannisa IA, Zikoudib A, Huga JS. 2008 Arsenic removal from groundwaters containing iron, ammonium, manganese and phosphate: A case study from a treatment unit in northern Greece. Desalination, 224(1-3): 330-339.

Knocke WR, Conley L, Van Benschoten JE. 1992 Impact of dissolved organic carbon 
on the removal of iron during water treatement. Wat. Res., 26(1): 515-1522.

Mazet M, angbo L, Serpaud B. 1990 Adsorption de substances humiques sur flocs d'hydroxyde d'aluminium préformés. Wat. Res., 24(12): 15091518.

Montiel A, Welte B. 1990 Le manganèse dans l'eau. Elimination du manganèse dans l'eau par traitement biologique. Rev. Sci. Eau, 3: 469-481.

Muwanga A, Barifaidjo E. 2006. Impact of industrial activities on heavy metal loading and their physico-chemical effects on wetlands of Lake Victoria basin (Uganda). AJST, 7(1): 51-63

Myint Z, Barry C . 1999. Iron and manganese dynamics in lake water. Water Res., 33(8): 1900-1910.

Llofd A, Grzeskowiak R, Mendham J. 1983. The removal of manganese in water treatment clarification processes. Water Res., 17(11): 1517-1523.

Okoniewsk E, Lacha J, Kacprzaka, Neczaja E. 2007 The removal of manganese, iron and ammonium nitrogen on impregnated activated carbon. Desalination, 206(1-3): 251-258.

Omoregie E, Okoronkwo MO, Eziashi AC, Zoakah AI. 2002. Metal concentrations in water column; benthic macro invertebrates and tilapia from Delimi river. Nigeria. Journal of Aquatic Sciences, 17(1): 55-59.

Qin S, Mab F, Huang P, Yang J. 2009 FeII and MnII removal from drilled well water: A case study from a biological treatment unit in Harbin. Desalination, 245(1-3): 183-193.
Roccaro P, Barone C, Mancini G, Vagliasindi FGA. 2007 Removal of manganese from water supplies intended for human consumption: a case study. Desalination, 210: 205-214.

Tekerlekopoulou AG, Vasiliadoua IA, Vayenas DV. 2008 Biological manganese removal from potable water using trickling filters. Biochem. Eng. J., 38(3): 292-301.

Tekerlekopoulou AG, Vayenas DV. 2007 Ammonia, iron and manganese removal from potable water using trickling filters. Desalination, 210(1-3): 225-235.

Teng Z, Huang JY, Fujita K, Satoshi T. 2001 Manganese removal by hollow fiber micro-filter. Membrane separation from drinking water. Desalination, 139: 411418.

Van Benschoten JE, Edzwald JK. 1990 Chemical aspects of coagulation using aluminum salts-II. Coagulation of fulvic acid using alom and polyaluminum chloride. Water Res., 24(12): 1527-1535.

Xiao F, Zhang B, Lee C. 2008 Effects of low temperature on aluminum III) hydrolysis: Theoretical and experimental studies. J. Environ. Sci., 20: 907-914.

Zhong LY, Bao-Yu G, Qin-Yan Y, Yan W. 2010 Effect of $\mathrm{pH}$ on the coagulation performance of Al-based coagulants and residual aluminum speciation during the treatment of humic acid-kaolin synthetic water. J. Hazard. Mater, 178(1-3): 596603. 